The above brief sketch is all that my leisure now enables me to give of the life of my friend Robert Lucas; but as soon as I find the leisure, I will endeavor to fill it up with such incidents as my long personal acquaintance with him enables me to furnish hereafter. And, I have long been collecting materials for biographical sketches of a large number of our first settlers-such as Governors Meigs, Morrow, Trimble, and Worthington; of our members of congress; of the general assembly; judges of the supreme court; our most distinguished lawyers, physicians, and divines. A future edition of this work will offer me a place for all such writ. ings or sketches.-Writings of Caleb Atwater, Columbus, O., 1833.

\title{
THE EASTERN BORDER OF IOWA AS SEEN BY EDWARD TANNER IN 1818.
}

Edward Tanner, of New Madrid county, Missouri Territory, was an elder brother of John Tanner, who when a boy was taken captive by Indians, in 1790, in one of their raids into Kentucky, and was carried off no one knew where. In one of his journeys in search of him Edward Tanner went up the Mississippi river. He left St. Louis on the 15th of August, 1818, in company with Thomas Forsyth, the longtime and faithful agent of the Sac Indians (Annass, v, 5467). An account of his voyage was published in The Detroit Gazette, Jan. 8, 15, 1819, and reprinted in Wisconsin Historical Collections, viii, 287-292.

The following extract relates to the eastern borcier of Iowa:

The Mississippi is generally from three-fourths of a mile to three miles wide, interspersed with numerous islands clothed with the richest growth of timber, but subject to inundation. The river is at no time so low as not to afford water sufficient to float crafts drawing four feet of water. There are two rapids in the river, but neither of them materially obstructs navigation. About ninety miles from Prairie du Chien, and seven miles from the west side of the Mississippi, is a lead mine which is worked by 
the Fox Indians. The women dig the ore, carry it to the river where they have furnaces, and smelt it. The mine is called De Buke's, and is very. rich and productive. The Indians have lately discovered another in the vicinity, only four feet below the surface, and said to be rich. So deeply rooted is the jealousy of the Indians, that they allow no trader to build his hut on the side of the river in the vicinity of these mines.

The first tribe of Indians after leaving St. Louis is the Oyiwayes (Ioways). This tribe live about one hundred miles from the west side of the Mississippi on the Menomonee (Des Moines) and have about four hundred warriors. The next tribe are the Sauks, who live on the Mississippi, and about four hundred iniles above St. Louis. They emigrated from the Ouisconsin about thirty-five years ago (1783). Their military strength is about eight hundred warriors, exclusive of old men and boys, divided into $t$ wo divisions of four hundred men. Each division is commanded by a war chief. The first are those most distinguished for deeds of valor; the second the ordinary warriors. They have also two village chiefs who appear to preside over the civil concerns of the nation.

The next tribe is the Fox Indians. This tribe have a few lodges on the east side of the Mississippi near Fort Armstrong, and about four miles from the Sauk village. At the mine De Buke they have another village and another on Turkey river, thirty miles below Prairie du Chien. Their whole military strength is about four hundred warriors. They are at this time in a state of war with the Sioux; and as the Sauks are in strict amity with the Fox Indians, and have the influence and control of them, they are also drawn into the war. This was in consequence of depredations committed by the Fox Indians on the Sioux.

A narrative of the captivity of John Tanner was published in 1820. It was edited by Edwin James, and reprinted in London, 1831. An interesting notice of Edwin James by George Frazee is in The Annals iv, 125-7.

W. S.

A BONA FIDE settler ought to be protected while he is striving to secure an honest home against the grasping speculator. $\mathrm{He}$ who could rob a settler of his home or improvements, takes so much property from him, and though his act may not be cognizable as a crime by the law, he is nevertheless as morally guilty of a crime as though it had been done in defiance of the law.-The Andrew Western Democrat, February 19, 1851. 
Copyright of Annals of Iowa is the property of State of Iowa, by \& through the State Historical Society of Iowa and its content may not be copied or emailed to multiple sites or posted to a listserv without the copyright holder's express written permission. However, users may print, download, or email articles for individual use. 